BULLETIN OF THE

AMERICAN MATHEMATICAL SOCIETY

Volume 77, Number 3, May 1971

\title{
THE ANNUAL MEETING IN ATLANTIC CITY
}

The seventy-seventh annual meeting of the American Mathematical Society was held at the Chalfonte-Haddon Hall in Atlantic City, New Jersey from Thursday, January 21 through Sunday, January 24, in conjunction with the Association for Symbolic Logic and the Mathematical Association of America. There were 3,513 registrants, including 2,325 members of the Society.

The forty-fourth Josiah Willard Gibbs Lecture, Ergodic theory and the geodesics on surfaces of negative curvature, was delivered by Professor Eberhard Hopf of Indiana University at 8:30 p.m. on Thursday, January 21. Professor Hopf was introduced by Professor Nathan Jacobson.

The Retiring Presidential Address was presented by Professor Oscar Zariski of Harvard University at 11:00 a.m. on Friday, January 22. His title was Some open questions in the theory of singularities. Professor Zariski was introduced by Professor Nathan Jacobson.

By invitation of the Committee to Select Hour Speakers for Summer and Annual Meetings, there were four invited addresses. Professor Dennis P. Sullivan of the Massachusetts Institute of Technology spoke on Symmetry in manifold theory. He was introduced by Professor William Browder of Princeton University. Professor Daniel G. Quillen of the Massachusetts Institute of Technology spoke on Cohomology of groups and algebraic $K$-theory. He was introduced by Professor Franklin Peterson of Massachusetts Institute of Technology. Professor Leopoldo Nachbin of the University of Rochester and Instituto de Matematica Pura e Aplicada, Rio de Janeiro, Brazil spoke on Recent developments in infinite dimensional holomorphy. He was introduced by Professor François Treves of Rutgers University. Professor Harry Kesten of Cornell University spoke on Some nonlinear stochastic growth models. He was introduced by Professor J. H. B. Kemperman of the University of Rochester.

Two Veblen Prizes were awarded on Saturday, January 23rd, one to Professor Dennis P. Sullivan of the Massachusetts Institute of Technology and the other to Professor Robion C. Kirby of the Jniversity of California at Los Angeles. The prizes were given in recognition of their work as follows: Dennis P. Sullivan, On the Hauptvermutung for manifolds, Bull. Amer. Math. Soc. 73 (1967), 598-600; Robion C. Kirby, Stable homeomorphisms and the annulus conjecture, Ann. of Math. (2) 89 (1969), 575-582.

The Conference Board of the Mathematical Sciences presented a 
panel discussion on Operations Research and Mathematics on Sunday, January 23. The annual meeting of the Rocky Mountain Mathematics Consortium was held on Friday, January 22. Dr. Yudell L. Luke of the Midwest Research Institute spoke on Sunday, January 24 , on Information retrieval systems for mathematical journals.

There were sixty sessions for contributed ten-minute papers, presided over by the following: Clifford H. Anderson, Gregory F. Bachelis, Karl F. Barth, George W. Batten, Sidney Birnbaum, Carl W. Bitzer, Volodymyr Bohun-Chudyniv, Robert H. Bowman, William Lee Bynum, Gail L. Carns, David R. Cecil, Donald B. Coleman, Harry B. Coonce, Frederick H. Croom, Ronald H. Dalla, Thaddeus G. Dankel, Garret J. Etgen, Raphael Finkelstein, Robert B. Fraser, Stephen H. Friedberg, Archie G. Gibson, Robert Gilmer, Myron Goldstein, Paul Gordon, Pierre A. Grillet, Joe A. Guthrie, Hyong T. Hahn, Charles A. Hall, Douglas Harris, James V. Herod, Richard E. Hodel, Joseph T. Howson, Jr., Paul C. Kainen, Wolfgang Kappe, William E. Kirwan, Richard B. Lakein, Roland E. Larson, Gary E. Lippman, Vincent O. McBrien, Joseph J. Malone, Jr., Paul Meyer, James E. Miller, James W. Noonan, Stanley E. Payne, Mark A. Pinsky, Irwin S. Pressman, Clifford R. Qualls, Chris Rorres, Walter A. Rosenkrantz, G. Thomas Sallee, Harvey L. Shapiro, A. L. Shields, Sankatha P. Singh, Michael S. Skaff, John H. Smith, Armond E. Spencer, Robert S. Spira, Donald F. St. Mary, Frank Stenger, Paul Willig.

Abstracts of papers presented at the meeting appear in the Notices of the American Mathematical Society for January, 1971.

The Arrangements Committee for the meeting consisted of Albert Schild, chairman, H. L. Alder, ex officio, F. Eugene Clark, Jesse P. Clay, Leonard Gillman, ex officio, Walter H. Gottschalk, Sam Newman, Clifford W. Sloyer, Jr., Gordon L. Walker, ex officio.

The Council met on January 20, 1971 at 2:00 P.M. in the West Room of Haddon Hall.

The Secretary announced the election of the following 82 persons to ordinary membership in the Society:

Alonso, Luis E. Viera, Av Colon 5010 P, Cordoba, Argentina

Andersen, Kenneth F., Royal Roads Military College

Beller, Elliot, Newark College of Engineering

Berman, Martin, United State Bureau of Mines

Bucuzzo, Joseph J., California State College at Fullerton

Butler, Geoffrey J., University of Alberta

Collins, Michael F., Southwest Minnesota State College

Conway, John P., Temple University

Dahlke, Harold S., LTV Aerospace Corporation

Davenport, William H., University of Alabama 
Florey, Francis G., Wisconsin State University-Superior

Foias, Ciprian Ilie, Indiana University

Frank, Peter, University of California, Santa Barbara

Friedman, Charles N., Princeton University

Garner, Lynn E., Brigham Young University

Germano, Giorgio M., Cons. Nazion. Delle Ricerche, Torino, Italy

Godfrey, William A., Unjversity of Kansas, School of Medicine

Gustafson, Grant B., University of Utah

Harner, Charles C., Sandia Corporation, Albuquerque, New Mexico

Harris, Daniel W., Houston Lighting \& Power Company, Houston, Texas

Harrod, Scott B., Western Illinois University

Hauer, Karl-Heinz, University of Göttingen, Göttingen, West Germany

Hayasi, Nisiki, 118 Valley View Drive, Smyrna, Georgia 30080

Helton, John C., West Virginia University

Hollins, Clinton G., Scanwell Labs, Springfield, Virginia

Hollis, Elmer G., Jr., United States Army

Holten, Robert P., University of Sierra Leone

Howard, James C., NASA, Ames Research Center, Moffett Field, California

Howell, Jo Ann, University of Texas at Austin

James, Michael J., Houston Lighting \& Power Company, Houston, Texas

Jamison, James E., Memphis State University

Kabele, Thomas G., University of Kansas

Kainen, Paul C., Case Western Reserve University

Kannan, Rangachary, Purdue University

Kaplan, James L., Northwestern University

Kerr, Robert A., Kerr \& Associates, Midland, Texas

Kim, Moon Wuki, Seton Hall University

Koh, Khee Meng, University of Manitoba

Lawson, Linda M., University of Tennessee

Leisenring, Albert C., Acadia University

Levy, Dorothy E., Cooper Union, New York, New York

Liebelt, Paul B., Pacific Lutheran University

Liu, Paul C., Great Lakes Research Center, Detroit, Michigan

Losey, Donald D., 2123 Linden Avenue, Newport, Kentucky

Lubenec, Pierre Y., 885 Centre Street, Newton, Massachusetts

Mahoney, Nelson T., State of Vermont, Highway Department, Montpelier, Vermont

McKean, Joel M., United States Air Force Academy

McReynolds, Samuel E., Jr., Abilene Christian College

Moser, Louise E., University of Wisconsin

Newton, Mervin E., Thiel College

Niederreiter, Harald G., Southern Illinois University

Nussbaum, Frank A., Loyola University

O'Donnell, Michael W., State University of New York, College at Oneonta

O'Neill, Larkin S., Ohio State University

Orlov, Konstantin, University of Belgrade, Belgrade, Yugoslavia

Perry, James M., Simplex Time Recorder Company, Rutland, Massachusetts

Reardon, Philip C., 10516 San Gabriel Road NE, Albuquerque, New Mexico

Ree, X. B., Jr., University of Florida

Regoczei, Stephen I. B., University of Toronto

Rhee, Haewun, State University of New York, College at Oneonta

Riley, James T., Wayne State University 
Rine, David Craig, West Virginia University

Rosenfeld, Ronald L., United States Navy

Sadik, Ali, University of Florida

Schraegle, Horst, University of Muenster, Muenster, West Germany

Scott, John B., Texaco Research Lab, Bellaire, Texas

Shih, Chung-Tuo, University of California, San Diego, California

Solomon, Benjamin J., Sierra Nevada College, Incline Village, Nevada

Steele, Charles A., Jr., Boston College, Chestnut Hill, Massachusetts

Stepp, James W., University of Houston

Stover, James A., Jr., Memphis State University

Swardstrom, Paul D., University of Minnesota

Tross, Ralph G., University of Ottawa

Turner, Gerald E., General Electric Company, Bethesda, Maryland

Van Tan, Tran, University of Saigon, Saigon, Vietnam

Waid, Margaret C., Texas Technological University

Walster, G. William, University of Wisconsin

Wehrly, Albert C., Fresno State College

Welsch, Roy E., Massachusetts Institute of Technology

Wilson, Richard M., Ohio State University

Worgul, Thomas J., Pennsylvania State University

Zaromp, Avigdor, Oakland University

It was announced that the following persons have been elected to membership in the Society in accordance with various reciprocity agreements:

Unión Matemática Argentina: Viera Alonso, Luis Ernesto.

Australian Mathematical Society: Donald H. Adams, Yu Kiang Leong, Rodney V.

Nillsen, Juraj Virsik, Ivor F. Vivian.

Sociêté Mathématique de Belgique: Michel Pierre Cahen, Jean-Marie E. Goethals.

Edinburgh Mathematical Society: Gambhir M. Shrestha.

Sociêté Mathématique de France: Antoine P. Brunel, G. Erik F. Thomas.

Gesellschaft für Angewandte Mathematik und Mechanik: Hellmut W. Weber.

Indian Mathematical Society: Ratan Shanker Mishra.

Israel Mathematical Union: Simeon S. Reich, Meir Smorodinsky.

The London Mathematical Society: Derek A. Waller.

Svenska Matematikersamfundet: Lars Inge Hedberg.

Schweizerische Mathematische Gesellschaft: Rene P. Held, Volker Strassen.

The following persons have been elected to membership in the Society upon nomination of institutional members as indicated:

Carnegie-Mellon University: Louis Thurston.

The Claremont Colleges: Steven F. Bellenot, Theodore W. Mogey, Henry J. Schultz.

Columbia University: Chiahua Pan.

Concordia College: Charles H. Jensvold.

Denison University: Andrew French, Jeffrey Jalbert, Laurence Kunes.

Eastern Montana College: Harbans Arora, William McKinley, John Mueller.

Indiana University: Richard T. Miller.

Lakehead University: Frank Ching-Tai Lin.

University of Maryland: Reinhold W. Remmert.

Miami University: Nazanin Bahrumiun, James R. Morrow.

University of Minnesota: Heinz M. Bruehlmann, Shlomo Horowitz, Joseph Shumi.

Montana State University: Gary W. Grefsrud. 
Morehouse College: Ben Almond.

University of Nebraska at Omaha: Vittoria Hamm, Roger L. Mansfield, Kris E. Peterson.

New York University: Ivan Stux.

University of Pennsylvania: Alexander Lyczak, Michael Rossman, Françoise Schremmer, Carl Widland.

Rutgers University: Edward A. Boyno, Steven N. Cichinski, John Empoliti, William Heck, Robert C. Miller, Jorge Viola Prioli, Rudy Rucker, David J. Slater, Peter Smith.

SUNY at Albany: Glenn G. Meyers.

SUNY at Stony Brook: Woodrow Dale Brownawell, William S. Clary, Joel Harkow.

University of Texas at Arlington: Michael Jones, Robert B. Patterson, Hal Willis.

Trinity College: Winston G. Davids.

Tufts Unversity: Anthony Sarantakis.

Wisconsin State University at Whitewater: Ronald D. Dettmers, Carroll E. Flanagan, Gary B. Klatt.

Worcester Polytechnic Institute: Francis L. Belisle, Jr., Philip H. Johnson, John W. Sundstrom.

University of Wyoming: Leslie Ann Hanson, Warren G. Sutton, Randy Jay York.

The Secretary announced the election of the following organizations to institutional membership:

Colgate University, Hamilton, New York

Iowa Wesleyan College, Mount Pleasant, Iowa

Towson State College, Baltimore, Maryland

Wilkes College, Wilkes-Barre, Pennsylvania

The Council approved the times and places of a number of meetings of the Society. The schedule now includes:

Summer Meeting, August 30-September 3, 1971 University Park, Pennsylvania

Annual Meeting, January 17-21, 1972

Summer Meeting, August 29-September 1, 1972 Hanover, New Hampshire

Annual Meeting, January 25-29, 1973

Summer Meeting, August 20-24, 1973

Las Vegas, Nevada

Hanover, New
Dallas, Texas

Missoula, Montana

The Secretary reported on the Election of 1971. The results, already published in the January issue on p. 176, are not repeated here.

At the same time it was noted that the Council elected Kenneth Ross to the position of Associate Secretary, replacing R. S. Pierce, who had resigned. The Committee to Monitor Problems in Communication elected Alex Rosenberg as its Chairman for 1971. By virtue of this election, he continues as a member of the Council. The Trustees elected Calvin Moore to be Trustee, filling the position of elected Trustee vacated by Nathan Jacobson, who, on accession to the post of President, became an ex officio Trustee.

The Council reaffirmed the charge of the Committee to Monitor Problems in Communication; namely, that this Committee should experiment with pilot projects with improved methods of communication, if such projects are approved by the Society and other organ- 
izations concerned, and that the result of these experiments be carefully assessed after a suitable trial period.

The Committee to Review Society Activities, consisting of Michael Atiyah, Morton Curtis, Samuel Eilenberg, Paul Halmos, William LeVeque, and Calvin C. Moore, Chairman, presented its final report, including fourteen specific recommendations. Some of these were recommendations for further study of special problems, and some were recommendations for no action in certain areas. However, several of the recommendations immediately affect the membership.

The Council approved the following Committee recommendation:

That efforts be made to markedly increase the average quality and to drastically decrease the number of Research Announcements in the Bulletin and that firm editorial control be exercised by the Editor.

The Council approved the following recommendation:

That the present cover-to-cover translations of Russian journals be continued, with a major cutback in the selected translation program in mathematics.

In connection with this recommendation, it should be observed that the increasing amount of cover-to-cover translation means that there is a smaller body of material available for consideration in the selected translation program.

It was noted that, as a result of a recommendation of the Moore committee, the Trustees had withdrawn a proposal to the Office of Science Information Services of the National Science Foundation for program definition of an information system in research mathematics.

Following another recommendation of the committee, a committee was appointed by the President to study the problem of establishing a cross referenced subject index to current literature.

The Council approved a recommendation that the requirement for key words for articles published in Society journals be dropped.

It was a recommendation of the Moore committee that ten-minute talks at Annual and Summer Meetings be discontinued for one year as an experiment. The Council was unwilling to agree with so drastic a step even as a one-year trial. The Council did resolve that at the Annual and Summer Meetings of 1972, the scheduling of ten-minute papers be substantially ignored in scheduling the remaining part of the program. The Committee to Select Hour Speakers has already been instructed greatly to increase the scientific strength of the meetings through invited speakers and specially planned sessions. The Associate Secretary in charge of the program is now free to schedule these in the most convenient way for building an effective program without making extraordinary efforts to avoid conflict with contributed papers. 
The Council approved the publication of a pamphlet, not yet formally titled, on the general subject of how to write a grant proposal, and on where and how to obtain information about sources of grant funds and areas of interest of grantors. It is concerned not only with support of research projects, but also with fellowships, with support of conferences, symposia, institutes, and seminars, and with various kinds and levels of departmental and institutional support.

During the deliberations, the Council adjourned for dinner at 5:55 P.M., reconvened at 8:10 P.M., and adjourned at 10:15 P.M.

The Business Meeting took place in the Pennsylvania Room of Haddon Hall on January 23, 1971. President Jacobson presided and called the meeting to order at 2:35 P.M.

The Secretary reported on various actions of the Council, including a number of the items in the preceding summary of Council actions.

The next item of business was a resolution placed on the agenda as the result of a motion of the Business Meeting of August 27, 1970 in Laramie, in accordance with Article X, Section 1, of the bylaws. The notification to the membership required in the bylaws can be found in the Notices, 17, p. 1009 and 18, pp. 3-4. The resolution was as follows:

That the Society shall poll its membership on the question: Are you in substantial agreement or disagreement with this statement:

I favor the prompt termination of American participation in the War in Southeast Asia, and the withdrawal of our troops with the greatest speed possible, limited only by the availability of transport and the safety of said troops regardless of the consequences to the present governments in Saigon and Phnom Penh.

Professor Anatole Beck, who introduced the resolution in Laramie, spoke at length in support of it.

Professor Moise offered a substitute motion in which the opinion poll of the entire membership would be replaced by the sense of those present and voting at the meeting. It was moved to table both the substitute motion and the original motion. The motion to table was defeated. The motion to substitute was defeated.

The original resolution was defeated by a vote of 276 to 294 .

The meeting was adjourned at 3:35 P.M.

Everett Pitcher

SECRETARY

Bethlehem, Pennsylvania

LeONARD Gilliman Associate Secretary

Austin, Texas 